\title{
Sensorineural deafness inherited as a tissue specific mitochondrial disorder
}

Lutfi Jaber, Mordechai Shohat, Xiangdong Bu, Nathan Fischel-Ghodsian, Hui-Ying Yang, Sue-Jane Wang, Jerome I Rotter

\begin{abstract}
We present here a large Israeli-Arab kindred with hereditary deafness. In this family 55 deaf subjects $(29 M, 26 F)$, who are otherwise healthy, have been identified and traced back five generations to one common female ancestor. The deafness is progressive in nature, usually presenting in infancy and childhood. Audiometry on six deaf and seven unaffected subjects was consistent with severe to profound sensorineural hearing loss. Based on formal family segregation analysis, the inheritance of deafness in this family closely fits the expectation of a two locus model owing to the simultaneous mutation of a mitochondrial gene and an autosomal recessive gene. Thus, this disorder appears to have the unusual features of being an inherited tissue specific mitochondrial disease and apparently requiring the homozygous presence of a nuclear gene for clinical expression. Most importantly, this disorder presents a unique opportunity to investigate the molecular basis of hereditary non-syndromic deafness and normal hearing.
\end{abstract}

Hereditary deafness is a heterogeneous group of disorders distinguished by their clinical manifestations and modes of inheritance. ${ }^{1}$ Most of the hereditary forms are sensorineural rather than conductive in nature, and $60 \%$ are non-syndromic, that is, not associated with any other abnormalities. ${ }^{2}$ It is estimated that 60 to $70 \%$ of cases with hereditary deafness are inherited in an autosomal recessive fashion, 20 to $30 \%$ are autosomal dominant, and $2 \%$ are $\mathrm{X}$ linked. ${ }^{3}$ Estimates of the number of gene loci involved in autosomal recessive deafness range from five to thousands, and additional genes must be involved in autosomal dominant and $\mathrm{X}$ linked deafness. ${ }^{45}$

The molecular basis for several syndromic forms of deafness have recently been linked to specific chromosomal areas, ${ }^{6-10}$ and in the case of some forms of Alport syndrome the defect has been localised to the type IV collagen $\alpha 5$ chain gene. ${ }^{11-13}$

We present here a large Israeli-Arab kindred with hereditary cochlear non-syndromic deafness, whose family aggregation is most consistent with a two locus mode of inheritance, one locus being mitochondrial and the other being autosomal recessive. This family provides for the first time the opportunity to elucidate the molecular basis leading to at least one kind of non-syndromic deafness.

\section{Subjects and methods}

The figure depicts the complete pedigree of this large kindred with deafness. All the family members live in an Israeli-Arab village 10 miles from Tel-Aviv. The proband had apparent hearing ability during the first year of life which allowed her to gain early speech skills. However, after the first year she experienced progressive hearing loss. Audiometric evaluation at 28 years showed profound deafness. Eight of her nine sibs as well as her mother were similarly affected. Subsequently, information regarding the rest of the members of this kindred was sought.

The pedigree data were collected through the various nuclear families that comprise this kindred. Information on affected subjects was always confirmed from first degree relatives. Fifty-five subjects were found to be affected. Most of them had no history of any hearing ability at any age; several, however, developed progressive hearing loss only after a few years of age, which allowed them to acquire lingual speech. Two subjects had normal hearing until adult age with no obvious cause for their late onset deafness (figure).

Six deaf and seven unaffected pedigree members underwent pure tone audiometry between 250 and $8000 \mathrm{~Hz}$, and ipsilateral and contralateral acoustic reflex measurements. Eight deaf subjects were examined in detail by history, physical examination, and basic laboratory tests such as blood counts and chemistries.

The familial segregation was initially analysed for mendelian genetic inheritance patterns by standard segregation analysis. ${ }^{14}$ Then two locus mitochondrial and autosomal gene models were examined in detail. ${ }^{15}$ The large pedigree was simplified to a maternal line pedigree only. Since all the members of such a pedigree share the same mitochondrial DNA, the analysis is reduced to a one autosomal locus model, with ' $A$ ' being the normal allele and ' $a$ ' being the mutated allele. The autosomal gene frequency $q$ was estimated from the observed segregation ratio for the pooled nuclear families with an affected mother (table 1). The estimated gene frequency from this group of families was then used to test the goodness of fit $\left(\chi^{2}\right)$ of each model on the pooled and individual nuclear families with an unaffected mother with at least one deaf offspring ${ }^{1617}$ (table 2). The power of this approach is that initial parameter estimation (gene frequency) and goodness of fit testing can be done in one portion of the pedigree (nuclear families with affected mothers), and then can be critically 


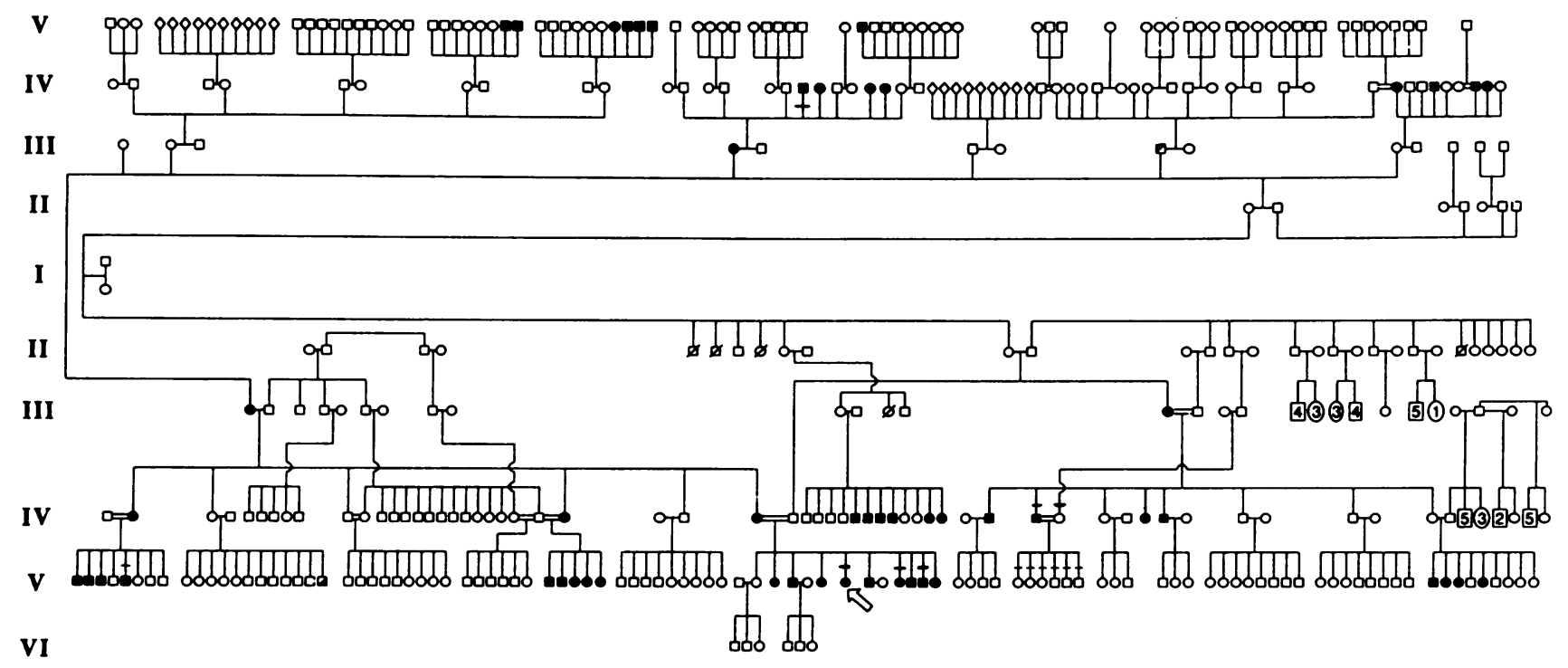

\begin{tabular}{|ll|}
\hline$\square 0$ Unaffected male, female & $\square=0$ Consanguineous mating or marriage \\
W० Deaf, onset in infancy or early childhood & 0 Sex unknown \\
$\square 0$ Deaf, onset in adulthood & $\square ठ$ Underwent audiometric tests \\
$\square \varnothing$ Died, no information available & $\square$
\end{tabular}

Israeli-Arab pedigree with sensorineural deafness.

Table 1 Expected proportions of deaf offspring under different mating types in maternally derived line of families.

\begin{tabular}{|c|c|c|c|c|}
\hline $\begin{array}{l}\text { Mode of } \\
\text { inheritance }\end{array}$ & $\begin{array}{l}\text { Mother's } \\
\text { status }\end{array}$ & Sibships & $\begin{array}{l}\text { Mating genotypes } \\
\text { (mother } \times \text { father) }\end{array}$ & $\begin{array}{l}\text { Exp proportions } \\
\text { of deaf offspring* }\end{array}$ \\
\hline \multirow{3}{*}{$\begin{array}{l}\text { Autosomal } \\
\text { recessive }\end{array}$} & Affected & All & aa $\times \mathbf{A A}$, aa $\times \mathbf{A a}$, aa $\times \mathbf{a a}$ & $\mathbf{q}$ \\
\hline & \multirow[t]{2}{*}{ Unaffected } & \multirow{2}{*}{$\begin{array}{l}\text { With at least one affected } \\
\text { offspring }\end{array}$} & \multirow[t]{2}{*}{$\mathbf{A a} \times \mathbf{A a}, \mathbf{A a} \times \mathbf{a a}$} & 1 \\
\hline & & & & $2(2-q)$ \\
\hline \multirow{4}{*}{$\begin{array}{l}\text { Autosomal } \\
\text { dominant }\end{array}$} & \multirow[t]{2}{*}{ Affected } & \multirow[t]{2}{*}{ All } & \multirow{2}{*}{$\begin{array}{l}\mathrm{Aa} \times \mathbf{A A}, \mathbf{A a} \times \mathbf{A a}, \mathbf{A a} \times \mathbf{a a} \\
\mathbf{a a} \times \mathbf{A A}, \mathbf{a a} \times \mathbf{A a}, \mathbf{a a} \times \mathbf{a a}\end{array}$} & $1+q-q^{2}$ \\
\hline & & & & $2-q$ \\
\hline & \multirow[t]{2}{*}{ Unaffected } & \multirow{2}{*}{$\begin{array}{l}\text { With at least one affected } \\
\text { offspring }\end{array}$} & \multirow[t]{2}{*}{$\mathbf{A A} \times \mathbf{A a}, \mathbf{A A} \times \mathbf{a a}$} & 1 \\
\hline & & & & $2-q$ \\
\hline
\end{tabular}

*These proportions are calculated using classical Hardy-Weinberg segregation laws. For example, in the autosomal recessive model with mother unaffected, the expected proportion of deaf offspring is equal to $\mathbf{P}$ (offspring from mating $\mathbf{A a} \times \mathbf{A a}$ is deaf) $\times \mathbf{P}(\mathbf{A a} \times \mathbf{A a})$

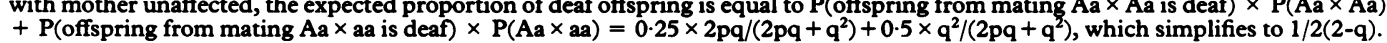

Table 2A Two locus mitochondrial and autosomal gene models: $\chi^{2}$ test for pooled sibships with unaffected mothers.

\begin{tabular}{|c|c|c|c|}
\hline Mode of inheritance & No of affected offspring & $\chi^{2}$ & $\mathbf{p}$ \\
\hline $\begin{array}{l}\text { Recessive } \\
\text { Observed } \\
\text { Expected }\end{array}$ & $\begin{array}{l}77 \times 0 \cdot 34=26 \cdot 15 \\
77 \times 1 /[2(2-0 \cdot 547)]=26 \cdot 50\end{array}$ & 0.007 & $>0.95$ \\
\hline $\begin{array}{c}\text { Dominant } \\
\text { Observed } \\
\text { Expected }\end{array}$ & $\begin{array}{l}77 \times 0.34=26.15 \\
77 \times 1 /(2-0.065)=39.79\end{array}$ & $9 \cdot 66$ & $<0.002$ \\
\hline
\end{tabular}

Table $2 B$ Two locus mitochondrial and autosomal gene models: $\chi^{2}$ test for individual sibships with unaffected mothers.

\begin{tabular}{|c|c|c|c|c|}
\hline \multirow[t]{2}{*}{ Sibship size } & \multirow[t]{2}{*}{ No of families } & \multicolumn{2}{|c|}{ No of affected offspring } & \\
\hline & & Observed & Expected & \\
\hline $\begin{array}{c}2 \\
7 \\
8 \\
9 \\
10 \\
12 \\
\text { Total }\end{array}$ & $\begin{array}{l}1 \\
1 \\
2 \\
2 \\
1 \\
2\end{array}$ & $\begin{array}{r}1 \\
3 \\
6 \\
5 \\
4 \\
7 \\
26\end{array}$ & $\begin{array}{r}1.2 \\
2.5 \\
5.6 \\
6.3 \\
3.5 \\
8.2 \\
27.3\end{array}$ & $\begin{array}{l}\chi^{2}=0.11 \\
p>0.73\end{array}$ \\
\hline
\end{tabular}

tested in another portion of the pedigree (nuclear families with unaffected mothers having at least one affected offspring). The observed segregation ratio of unaffected mothers with at least one deaf offspring was adjusted for ascertainment bias by the standard proband method. ${ }^{1819}$

Mitochondrial restriction fragment length polymorphism analysis was performed in four deaf members of the pedigree and two normal unrelated controls. DNA was isolated from blood samples, and $5 \mu \mathrm{g}$ aliquots were then digested with restriction enzymes, subjected to electrophoresis in $1 \%$ agarose gels, and transferred to nytran filters. ${ }^{20}$ Blots were hybridised with ${ }^{32} \mathrm{P}$ labelled whole mitochondrial DNA (supplied by Uzi Rita, Jerusalem, Israel) at $65^{\circ} \mathrm{C}$ for 24 hours in buffer containing $1 \%$ bovine serum albumin, $1 \mathrm{mmol} / 1$ EDTA, $0.5 \mathrm{~mol} / 1$ sodium phosphate, and $7 \%(\mathrm{w} / \mathrm{v})$ sodium dodecyl sulphate. Filters were washed twice in $2 \%$ and twice in $0.1 \%(\mathrm{w} / \mathrm{v})$ sodium 
dodecyl sulphate, each time for 15 minutes at $65^{\circ} \mathrm{C}$. The filters were exposed to Kodak XAR film at $-70^{\circ} \mathrm{C}$.

\section{Results}

Audiometric studies indicated severe to profound sensorineural hearing loss of at least -70 decibels for all frequencies, as well as decreased contralateral acoustic reflex threshold, in all the deaf subjects. Normal results were obtained in all unaffected pedigree members. These results are most consistent with a cochlear lesion, although a retrocochlear lesion cannot be excluded yet. General examination of deaf subjects showed no abnormalities in general state of health, gross vestibular function, and other organ systems frequently associated with mitochondrial disorders (neurological, muscle) or with hearing deficits (kidneys, eyes).

Pedigree analysis showed that the 55 deaf subjects could all be traced back to one original couple (generation I in the figure), and transmission of the disease occurred only through the maternal line.

Transmission by mendelian autosomal or $\mathrm{X}$ linked inheritance alone could be summarily rejected by the following reasoning. With one or multiple autosomal locus modes of inheritance the expected number of deaf offspring of either deaf or unaffected fathers should be equal to that of the respective mothers. However, 29 deaf offspring were born to six of seven deaf mothers and 26 to 15 unaffected mothers, while not a single deaf offspring was born to either of the six deaf or 11 unaffected fathers descended from the ancestral couple. Similarly, $\mathrm{X}$ linked recessive inheritance was rejected because of the nearly even proportion of male and female patients affected ( 29 males, 26 females). X linked dominant inheritance was rejected because none of the 15 daughters of deaf males, who would be obligate carriers of the defect, was affected.

The maternal inheritance by non-mendelian genetic factors could be explained by either of two genetic mechanisms: imprinting ${ }^{21}$ and mitochondrial inheritance. Imprinting with full penetrance could be rejected because of the different segregation ratios in affected and unaffected mothers with at least one affected offspring $(0.55$ and 0.34 , respectively; $\mathrm{p}<0.03)$. Imprinting with partial penetrance could be rejected because the observed segregation ratio in affected mothers is 0.55 and the expected segregation ratio in imprinting with partial penetrance is $<0.5$. In addition, no transmission occurred from an affected male to any of his nine grandchildren through three daughters.

The transmission of deafness is completely compatible with mitochondrial inheritance. However, mitochondrial inheritance with full penetrance is an inadequate explanation because of the many unaffected offspring of deaf mothers. Mitochondrial inheritance requiring environmental factors for expression is also highly unlikely, given the early onset of disease, and the homogeneous environment within the village. The two remaining most parsimonious hypotheses for the genetic transmission pattern in this kindred are therefore (1) a two locus disease with the simultaneous involvement of a mitochondrial gene and an autosomal gene, and (2) mitochondrial inheritance with varying amounts of heteroplasmy.

The autosomal gene frequency estimated from pooled deaf mothers under the autosomal recessive case is $q=0.547$, and under the autosomal dominant case $q=0.065$. When tested on pooled sibships from unaffected mothers, there was remarkably close agreement between the expected and observed segregation ratios for the autosomal recessive model, while the autosomal dominant model could clearly be rejected (table $2 \mathrm{~A}$ ). Similarly, table $2 \mathrm{~B}$ shows for individual sibships that there is good agreement with the autosomal recessive model. The autosomal dominant model could again be rejected $\left(\chi^{2}=8.93, p<0.003\right)$

Mitochondrial DNA analysis showed no evidence for deletions/duplications, or heteroplasmy, with the following enzymes: TaqI, BamHI, KpnI, StyI, Sau3AI, AluI, BstNI, HaeIII, HinfI, and DdeI.

\section{Discussion}

In the large Israeli-Arab kindred presented here, progressive sensorineural deafness was most likely to be caused by the simultaneous inheritance of a mitochondrial mutation and an autosomal recessive mutation. This is based both on the rejection of alternative models, and the excellent fit between the model and the observed family segregation in the aggregate and within individual nuclear sibships. Heteroplasmy of the mitochondrial mutation is the second most likely explanation for the deafness aggregation in this family. Although most mitochondrial deletion mutations leading to disease are heteroplasmic, several lines of evidence, in addition to the molecular studies to date, make mitochondrial inheritance with heteroplasmy unlikely in this pedigree. Most importantly, the clinical phenotype is relatively homogeneous within each family, between families, and between generations, with most subjects developing deafness in infancy or early childhood, making a dose effect less likely. In addition, there are only very few descriptions of a stable passage of heteroplasmic mitochondrial DNA from one generation to the next, ${ }^{22-24}$ heteroplasmy is virtually absent in the general population despite a high mitochondrial mutation rate, ${ }^{25-27}$ and in vitro injections of mitochondria into cells lead to rapid replacement of endogenous mitochondrial DNA. ${ }^{28}$ Nevertheless, the final answer regarding heteroplasmy must await the molecular identification of the mitochondrial mutation.

The high frequency of the autosomal gene could be explained in three possible ways. First, it could be a common polymorphism in one of the nuclear encoded oxidative phosphorylation subunits, which leads to disease only in association with the special mitochondrial genotype in this family. Second, it could 
be the result of a high frequency of consanguineous matings, and, third, because of a founder effect in our study population. It is common among Israeli-Arabs who live in the villages to prefer consanguineous marriages, particularly among first cousins. In addition, such villages are often populated by a few $(<20)$ original families. However, consanguineous marriages in the Israeli-Arab community are usually through the paternal side, with the goal of conserving the lands within the family, and thus cannot explain the maternal transmission observed in this family.

The tissue specificity of this disease is intriguing. The mitochondrial genome codes for 13 of the approximately 70 subunits engaged in oxidative phosphorylation, and oxidative phosphorylation is ubiquitous in all nucleated human cells. Most inherited mitochondrial disorders affect a number of tissues, and in particular those with the highest energy requirements such as striated muscle and nerves. ${ }^{2930}$ However, LHON is mainly limited to the optic nerve, and has recently been shown to be a two locus disease with one mitochondrial point mutation and one locus linked to $D X S 7$ on the $\mathrm{X}$ chromosome. ${ }^{31-33} \mathrm{It}$ is possible to speculate, both for LHON and our deafness pedigree, that a mutation affects a tissue specific isoform of a nuclear encoded oxidative phosphorylation subunit, which interacts with the mutated mitochondrial encoded subunit, and leads to tissue specific disease. Although such isoforms have not been reported in humans, they have been described in other species. ${ }^{34}$ Alternatively, it is possible that the mutated mitochondrial subunit functions normally in oxidative phosphorylation in our pedigree, but interacts abnormally with a hearing specific protein encoded by the nuclear locus.

Our pedigree presents a unique opportunity to investigate for the first time the molecular basis of non-syndromic deafness. The mitochondrial mutation can be identified because of the small size of the mitochondrial chromosome, ${ }^{35}$ and identification of the autosomal locus is greatly simplified by the power of linkage analysis in this large kindred and the likely interaction between the mitochondrially encoded and autosomally encoded proteins.

Other mitochondrial DNA defects can lead to deafness, as evidenced by the recent description of 22 pedigrees with deafness caused by mitochondrial transmitted susceptibility to aminoglycosides. ${ }^{36}$ It is possible that the mitochondrial DNA mutation in these cases is similar to the one in our pedigree, and that the phenotypic expression can be induced either by an autosomal recessive mutation or by the aminoglycosides. It can also be speculated that one of the common forms of acquired hearing loss, strial presbyacusis, in which decreased oxidative phosphorylation activity in the stria vascularis has been documented, ${ }^{37}$ is related to mitochondrial DNA degeneration with age. ${ }^{3839}$ These data suggest that the molecular study of mitochondrial organelles will lead to an elucidation of biochemical pathways involved in hearing and hearing deficits.
This work was supported in part by NIH grant DC01402, grant no 88-00098 from the US-Israel BSF, Jerusalem, and the Cedars-Sinai Board of Governors' Chair in Medical Genetics (JIR).

1 McKusick VA. Mendelian inheritance in man: catalogs of autosomal dominant, autosomal recessive, and $X$-linked phenotypes. Baltimore: The Johns Hopkins University Press, 1990: 252-4, 1132-5, 1583-5.

2 Beighton P. Hereditary deafness. In: Emery AEH, Rimoin DL, eds. Principles and practice of medical genetics. 2nd ed. Edinburgh: Churchill Livingstone, 1990.

3 Konigsmark BW, Gorlin RJ. Genetic and metabolic deafness. Philadelphia: Saunders, 1976.

4 Chung CS, Brown KS. Family studies of early childhood deafness ascertained through the Clarke school for the deaf. Am $\mathcal{f}$ Hum Genet 1970;22:630-44.

5 Sank D. Genetic aspects of early total deafness. In: Rainer JD, Altshuler KZ, Kallman FJ, eds. Family and mental JD, Altshuler KZ, Kallman FJ, eds. Family and mental
health problems in a deaf population. New York: New York health problems in a deaf population.

6 Kimberling WJ, Weston MD, Moeller C, et al. Localization of Usher syndrome type II to chromosome 1q. Genomics
of 1990;7:245-9.

7 Lewis RA, Otterud B, Stauffer D, Lalouel J-M, Leppert M. Mapping recessive ophthalmic diseases: linkage of the locus for Usher syndrome type II to a DNA marker on chromosome 1q. Genomics 1990;7:250-6.

8 Foy C, Newton V, Wellesley D, Harris R, Read AP. Assignment of the locus for Waardenburg syndrome type I to human chromosome 2q37 and possible homology to the splotch mouse. Am $\mathcal{Y}$ Hum Genet 1990;46:1017-23.

9 Shiloh Y, Litvak G, Ziv Y, et al. Genetic mapping of Xlinked albinism-deafness syndrome (ADFN) to Xq26.3q27.1. Am $\mathcal{Y}$ Hum Genet 1990;47:20-7.

$10 \mathrm{Ngo}$ JT, Bateman JB, Spence MA, et al. Ornithine aminotransferase (OAT): recombination between an X-linked OAT sequence $(7.5 \mathrm{~kb})$ and the Norrie disease locus. Genomics 1990;6:123-8.

11 Barker D, Hostikka SL, Zhou J, et al. Identification of mutations in the COL4A5 collagen gene in Alport syndrome. Science 1990;248:1224-7.

12 Zhou J, Hostikka SL, Chow LT, Tryggvason K. Characterization of the $3^{\prime}$ half of the human type IV collagen $\alpha 5$ gene that is affected in the Alport syndrome. Genomics 1991;9:1-9.

13 Zhou J, Barker DF, Hostikka SL, Gregory MC, Atkin CL, Tryggvason K. Single base mutation in a5(IV) collagen chain gene converting a conserved cysteine to serine in Alport syndrome. Genomics 1991;9:10-8.

14 Emery AEH. Segregation analysis. In: Methodology in med ical genetics. An introduction to statistical methods. 2nd ed. Edinburgh: Churchill Livingstone, 1986:37-54.

15 Bu X, Yang H-Y, Shohat M, Rotter JI. Two-locus mitochondrial and nuclear gene models for mitochondrial disorders. Am f Hum Genet 1990;47:128A.

16. Smith CAB. A test for segregation ratios in family data. Ann Hum Genet 1956;20:257-65.

17 Crow JF. Problems of ascertainment in the analysis of family data. In: Neel JV, Shaw MW, Schull WJ, eds. Genetics and the epidemiology of chronic diseases. WashGenetics and the epidemiology of chronic diseases. Washington, DC: US Department of Health, Ed
Welfare, Public Health Service, 1965:23-60.

18 Weinberg W. Methoden und Fehlerquellen der Untersuchung auf Mendleschen Zahlen beim Menschen. Arch Rass $u$ Ges Biol 1912;9:165-74.

19 Fisher RA. The effects of methods of ascertainment upon the estimates of frequencies. Ann Eugen 1934;6:13-25.

20 Southern EM. Detection of specific sequences among DNA fragments separated by gel electrophoresis. $\mathcal{f} \mathrm{Mol} \mathrm{Biol}$ 1975;98:503-17.

21 Hall JG. Genomic imprinting: review and relevance to human diseases. Am $\mathcal{f}$ Hum Genet 1990;46:857-73.

22 Lott MT, Voljavec AS, Wallace DC. Variable genotype of Leber's hereditary optic neuropathy patients. $A m \mathcal{F} O \mathrm{ph}$ thalmol 1990;109:625-31.

23 Vilkki J, Savontaus M-L, Nikoskelainen EK. Segregation of mitochondrial genomes in a heteroplasmic lineage with Leber's hereditary op
Genet 1990;47:95-100.

24 Shoffner JM, Lott MT, Lezza AMS, Seibel P, Ballinger SW, Wallace DC. Myoclonic epilepsy and ragged-red SW, Wallace DC. Myoclonic epilepsy and ragged-red fiber disease (MERRF) is associated with a mi
DNA tRNA ${ }^{\mathrm{Lys}}$ mutation. Cell 1990;61:931-7.

25 Brown WM, George M, Wilson AC. Rapid evolution of animal mitochondrial DNA. Proc Natl Acad Sci USA 1979;76:1967-71

26 Monnat RJ, Loeb LA. Nucleotide sequence preservation of human mitochondrial DNA. Proc Natl Acad Sci USA 1985;82:2895-9.

27 Cann RL, Stoneking M, Wilson AC. Mitochondrial DNA and human evolution. Nature 1987;325:31-6.

28 King MP, Attardi G. Injection of mitochondria into human cells leads to a rapid replacement of the endogenous mitochondrial DNA. Cell 1988;52:811-9.

29 Shoffner JM, Wallace DC. Oxidative phosphorylation diseases: disorders of two genomes. Adv Hum Genet 1990;19:267-330.

30 Menkes JH. Genetic disorders of mitochondrial function. $\mathcal{f}$ I'ediatr 1987;110:255-9.

31 Wallace DC, Singh G, Lott MT, et al. Mitochondrial DNA mutation associated with Leber's hereditary optic neuropathy. Science 1988;242:1427-30. 
32 Vilkki J, Ott J, Savontaus M-L, Aula P, Nikoskelainen EK. Optic atrophy in Leber hereditary optic neuroretinopathy Optic atrophy in Leber hereditary optic neuroretinopathy
is probably determined by an X-chromosomal gene is probably determined by an X-chromosomal gene
closely linked to DXS7. Am $₹$ Hum Genet $1991 ; 48: 486-91$. $33 \mathrm{Bu} \mathrm{X}$, Rotter JI. X-chromosome linked and mitochondrial gene control of Leber hereditary optic neuropathy: evidence from segregation analysis for dependence on $\mathrm{X}$ chromosome inactivation. Proc Natl Acad Sci USA (1991;88:8198-202).

34 Capaldi RA, Gonzalez-Halphen D, Zhang YZ, Yanamura $W$. Complexity and tissue specificity of the mitochondrial respiratory chain I Biome Biomembr 1988;20:291-31

35 Anderson S, Bankier AT, Barrell BG, et al. Sequence and organization of the human mitochondrial genome. Nature 1981;290:457-65.
$36 \mathrm{Hu}$ D-N, Qiu W-Q, Wu B-T, et al. Genetic aspects of antibiotic induced deafness: mitochondrial inheritance. $\mathcal{F}$ antiotic induced deafness:

37 Schuknecht HF. Pathology of the ear. Cambridge, Mass: Harvard University Press, 1974:388-408.

38 Linnane AW, Marzuki S, Ozawa T, Tanaka M. Mitochondrial DNA mutations as an important contributor to ageing and degenerative diseases. Lancet 1989;i:642-5.

39 Cortopassi GA, Arnheim N. Mitochondrial DNA deletion in normal adult humans detected by PCR. Am $\mathcal{f}$ Hum Genet 1990;47(suppl.):395A. 